\title{
The Use of Shunting Devices for Cerebrospinal Fluid in Canada
}

\author{
Harold J. Hoffman and May S.M. Smith
}

\begin{abstract}
The use of diversionary CSF shunting devices for the treatment of hydrocephalus has been surveyed in Canada. Various factors influencing the operation of shunting devices, the characteristics of commercial shunts and the causes of shunt malfunction are described. Suggestions are made as to how to reduce the incidence of shunt malfunction.
\end{abstract}

RÉSUMÉ: L'emploi de dispositifs de dérivation du liquide céphalo-rachidien au Canada L'utilisation de dispositifs de dérivation du liquide céphalo-rachidien pour le traitement de l'hydrocéphalie a été étudiée au Canada. Différents facteurs influençant le fonctionnement des dispositifs de dérivation, les caractéristiques des dérivations commerciales et les causes de dysfonction sont décrites. Les auteurs font des suggestions quant aux moyens de réduire l'incidence de dysfonction des dérivations.

Can. J. Neurol. Sci. 1986; 13:81-87

The Bureau of Medical Devices was established within the Department of Health and Welfare of Canada to set up criteria for implantable devices. We were charged with preparing a report on devices used for shunting cerebrospinal fluid in Canada.

In his recent historical review on the surgical treatment of hydrocephalus, Robert Pudenz (1) states "During my residency training years in Montreal . . . Wilder Penfield remarked that any neurosurgeon worth his salt would, at some time in his career, confront the problems of hydrocephalus and seek better methods of medical and surgical management". Pudenz concluded his review with the statement "nevertheless, as we approach the end of the 20th century, we still have far to go in finding solutions to the many problems faced by patients with hydrocephalus".

Despite the work of numerous investigators and the fact that several commercial companies are actively involved in the improvement of shunting devices for the treatment of hydrocephalus, we still do not have an ideal device for the management of a condition where proper treatment might restore the patient to normal function.

\section{Medical Device Legislation in Canada}

In Canada, the marketing of medical devices is regulated under Sections 19-21 of the Food and Drugs Act and the Medical Devices Regulations. The Act makes it an offense for any person to sell a device which is unsafe when used according to instructions, does not perform according to claims, is mislabelled, contaminated or does not comply with a mandatory standard. It must be noted that there is no authority or mechanism under the Food and Drugs Act to approve a medical device prior to its sale in Canada. It is the responsibility of the manufacturer to ensure that the regulatory requirements are met. However, the regulations do require the manufacturer or vendor of a device to inform the Bureau of Medical Devices of what is being sold in Canada, to supply test results in support of the performance and safety of the device and to ensure that the product is adequately labelled. Adequate records of all problems reported and corrective actions taken must be kept and the Bureau must be notified of recalls and similar actions.

The devices designed for implantation into tissues or body cavities for 30 days or more, as well as others listed in Table 1 of the Medical Devices Regulations, are subject to premarket review under Part $V$ of the regulations and a "Notice of Compliance" must be obtained by the manufacturer before the device may be sold in Canada. The purpose of premarket review is to ensure that all necessary evaluations have been conducted by the manufacturer and that the test results demonstrate reasonable safety in humans.

\section{Shunting Devices}

Prior to the development of shunting devices, hydrocephalus was a disorder which in most cases produced severe cerebral dysfunction and death.

In the late 19th century, a number of largely unsuccessful techniques were begun in an effort to divert CSF. The first

From the Division of Neurosurgery. The Hospital for Sick Children, University of Toronto. Toronto. Ontario (Dr. Hoffman) and Clinical Criteria Bureau of Medical Devices, Environmental Health Directorate, Health Protection Branch. Health and Welfare Canada, Ottawa, Ontario (Dr. Smith)

Received August 13, 1985. Accepted February 11, 1986

Reprint requests to: Dr. Harold J. Hoffman, Division of Neurosurgery, The Hospital for Sick Children, 555 University Ave., Toronto. Ontario, Canada M5T 1 X8 
successful diversionary shunt was devised by Torkildsen ${ }^{2}$ in 1939 and consisted of a rubber catheter which was led from the lateral ventricle to the cisterna magna, bypassing obstructions in the region of the third ventricle and aqueduct of Sylvius. The Torkildsen shunt remains a very effective diversionary shunt. It is not prone to problems of growth which affect other shunts in the growing child. However, it requires a much more prolonged and difficult operative procedure than the usual CSF shunts and consequently remains unpopular. Furthermore, the relatively small cisterna magna of infants results in a high failure rate and poor function.

Shunts from the lumbar subarachnoid space were first inserted in 1949. ${ }^{3}$ Initially, they were directed to the ureter, this involved the removal of one kidney. Subsequently, the shunts were directed from lumbar subarachnoid space into the peritoneal cavity, and lumboperitoneal shunts have continued to be a relatively popular form of diversionary CSF shunting. These shunts can only be used when there is free communication of fluid from the ventricles through to the lumbar subarachnoid space. They cannot be used if there is an obstructing lesion within the ventricular system.

Lumboperitoneal shunts fell into disfavour in the 1960's because of problems of arachnoiditis progressive neurologic deficit and kyphoscoliosis. ${ }^{4}$ The major cause of this was the use of polyethylene in the shunting tubes. Since the early 70 's however, all diversionary shunts have been made of silastic and with the initiation of silastic lumboperitoneal shunts, both by open and percutaneous techniques, the problems of arachnoiditis have largely vanished, making for an increased popularity of this type of shunt. ${ }^{5}$

Nulsen and Spitz reported on their use of a valvular shunt in 1952 (6). With the development of the unidirectional valvular shunt, it became possible for CSF to be shunted from the lateral ventricle to the venous side of the circulation. The initial valvular shunts were ventriculoatrial shunts. However, these shunts carry a significant risk of morbidity and mortality because of the development of thrombus around the tip of the shunt, the subsequent pulmonary emboli lead eventually to pulmonary hypertension, corpulmonale, intractable heart failure and death.

Ventriculopleural shunts were initially advocated by Ransohoff ${ }^{7}$ and continue to be useful. ${ }^{8}$ They have fallen into disrepute because of the high incidence of poor absorption of CSF from the pleural cavity and the development of pleural effusions.
Numerous other sites have been advocated for the shunting of CSF. These include the fallopian tubes of females, the stomach, the gallbladder, the salivary glands, the middle ear, the lymphatic ducts, and the major dural venous sinuses. All of these sites have been prone to significant problems and are rarely used for treating hydrocephalus.

The commonest site for the diversion of CSF is the peritoneal cavity and ventriculo-peritoneal shunts are the most common type carried out today. A major disadvantage of this shunt is the long length between the head and peritoneal cavity and the problems created by growth of the patient, particularly when the patient is a small infant. In recent years, the development of non-kinkable silastic tubing has allowed for long lengths of tubing to be left in the peritoneal cavity so that it can pull out of the peritoneal cavity with growth, allowing the shunt to continue to function.

Shunts are relatively costly devices. The one-piece shunts sell for $\$ 357.50$. The multicomponent shunting devices consist of a ventricular catheter, a distal peritoneal catheter and an interposed flushing device and/or valve. Ventricular catheters range in price from $\$ 40$ to $\$ 90$. Non-valvular flushing devices vary in price between $\$ 35$ and $\$ 235$. The flushing device with valve and anti-siphon device is $\$ 345$. Distal peritoneal catheter vary in price between $\$ 44$ and $\$ 95$. The connectors which link these individual components range from $\$ 7.00$ to $\$ 60.50$. A multicomponent system is marketed for about $\$ 500$.

The surgical fees for shunt placement and revision vary widely across Canada. Shunt insertion fees vary from a high of $\$ 894$ in Alberta to a low of $\$ 267.90$ in Ontario. Shunt revision fees vary from a high of $\$ 459.90$ in British Columbia to a low of $\$ 183.95$ in Ontario.

The patient with hydrocephalus who is admitted to hospital for shunt insertion or revision may spend anywhere from 5 to 20 days in hospital. If the per diem cost is $\$ 500$ the hospital bill would average $\$ 6,000$.

\section{Diversionary Shunt Procedures in Canada (Tables 1-5)}

During the year 1982-1983, 3,162 shunt procedures were done in Canada. Nineteen hundred seventy-three were shunt insertions, and 1,189 were shunt revisions. Based on population, the number of insertions varied between I per 5,000 in Nova Scotia to 1 per 20,000 in Manitoba.

Table 1: Diversionary Shunt Procedures in Canada 1982-1983

\begin{tabular}{|c|c|c|c|c|c|c|c|c|c|c|c|}
\hline Province & VP & VA & $\begin{array}{r}\text { Torkildsen } \\
\text { (Shunt }\end{array}$ & $\begin{array}{l}\text { LP } \\
\text { Insert }\end{array}$ & $\begin{array}{l}\text { Undesignated } \\
\text { ons) }\end{array}$ & Total & $\begin{array}{c}\text { Shunt } \\
\text { Revisions }\end{array}$ & $\begin{array}{l}\text { Total Shunt } \\
\text { Procedures }\end{array}$ & Population & $\begin{array}{c}\text { Insert/ } \\
\text { Population }\end{array}$ & $\begin{array}{l}\text { Procedure/ } \\
\text { Population }\end{array}$ \\
\hline Alberta & - & - & - & - & 196 & 196 & 144 & 340 & $2,350,000$ & $1 / 11,990$ & $1 / 6,912$ \\
\hline British Columbia & - & - & - & - & 197 & 197 & 145 & 342 & $2,823,900$ & $1 / 14,335$ & $1 / 8,527$ \\
\hline New Brunswick & 60 & 1 & 0 & 4 & 29 & 94 & 44 & 138 & 706,700 & $1 / 7,518$ & $1 / 5,121$ \\
\hline Newfoundland & 51 & 0 & 0 & 4 & 0 & 55 & 26 & 81 & 577,900 & $1 / 10,507$ & $1 / 7,135$ \\
\hline Nova Scotia & 146 & 8 & 0 & 10 & 0 & 164 & 94 & 258 & 859,300 & $1 / 5,240$ & $1 / 3,331$ \\
\hline Prince & & & & & & & & & & & \\
\hline Edward Island & 0 & 0 & 0 & 0 & 0 & 0 & 0 & 0 & 124,000 & \multirow{4}{*}{\multicolumn{2}{|c|}{$\begin{array}{l}\text { Patients transferred to } \\
\text { neighbouring provinces }\end{array}$}} \\
\hline Yukon & 0 & 0 & 0 & 0 & 0 & 0 & 0 & 0 & 22,200 & & \\
\hline Northwest & & & & & & & & & & & \\
\hline Territories & 0 & 0 & 0 & 0 & 0 & 0 & 0 & 0 & 48,000 & & \\
\hline TOTAL & 897 & 64 & 6 & 85 & 921 & 1,973 & 1,189 & 3,162 & $24,889,700$ & $1 / 12,615$ & $1 / 7,872$ \\
\hline
\end{tabular}


Table 2: Designated Shunts Inserted in Canada 1982-1983

\begin{tabular}{llrr}
\hline \hline Ventriculo-peritoneal shunt & (VP) & 897 & $85.2 \%$ \\
Ventriculo-atrial shunt & (VA) & 64 & $6.1 \%$ \\
Ventriculo-cisternostomy & (Torkildsen) & 6 & $0.6 \%$ \\
Lumbo-peritoneal shunt & (LP) & 85 & $\mathbf{8 . 1 \%}$ \\
& TOTAL & 1,052 & $100.0 \%$ \\
\hline
\end{tabular}

Table 3: Shunt Insertions According to Age and Sex 1982-1983 (Quebec and New Brunswick only)

\begin{tabular}{|c|c|c|c|c|c|c|}
\hline \multirow{2}{*}{$\begin{array}{c}\text { AGES } \\
<1 \text { year } \\
1-9 \\
10-19\end{array}$} & \multicolumn{2}{|c|}{$\begin{array}{c}\text { Quebec } \\
\text { Male Female } \\
\end{array}$} & \multicolumn{2}{|c|}{$\begin{array}{c}\text { New } \\
\text { Brunswick }\end{array}$} & \multicolumn{2}{|c|}{$\begin{array}{c}\text { Total } \\
\text { Male Female } \\
\end{array}$} \\
\hline & $\begin{array}{l}52 \\
33 \\
22 \\
\end{array}$ & $\begin{array}{l}35 \\
36 \\
21 \\
\end{array}$ & $\begin{array}{l}7 \\
9 \\
3 \\
\end{array}$ & $\begin{array}{r}7 \\
14 \\
8 \\
\end{array}$ & $\begin{array}{l}59 \\
42 \\
25 \\
\end{array}$ & $\begin{array}{l}42 \\
50 \\
29 \\
\end{array}$ \\
\hline TOTAL CHILDREN & 107 & 92 & 19 & 29 & 126 & 121 \\
\hline $\begin{aligned} & 20-29 \\
30-59 & \\
> & 60\end{aligned}$ & $\begin{array}{l}17 \\
43 \\
43 \\
\end{array}$ & $\begin{array}{l}11 \\
31 \\
33 \\
\end{array}$ & $\begin{array}{r}4 \\
9 \\
12 \\
\end{array}$ & $\begin{array}{l}5 \\
7 \\
5 \\
\end{array}$ & $\begin{array}{l}21 \\
52 \\
55 \\
\end{array}$ & $\begin{array}{l}16 \\
38 \\
38 \\
\end{array}$ \\
\hline TOTAL ADULTS & 103 & 75 & 25 & 17 & 138 & 92 \\
\hline TOTAL PATIENTS & 210 & 167 & 44 & 46 & 264 & 213 \\
\hline TOTAL & & 77 & & 90 & & 77 \\
\hline
\end{tabular}

Conclusions:

1. Slight male preponderance, particularly in adult population - may reflect higher incidence of traumatic hydrocephalus.

2. Commonest age group for insertion is infants under one year. These comprise $21 \%$ of the total shunt insertion population and $41 \%$ of the child population.

3. Children (under 19 years of age) make up $52 \%$ of the total shunt insertion population. Thus, hydrocephalus is as common in the adult population as in the pediatric population.

Table 4: Shunt Revision According to Age and Sex 1982-1983 (Quebec and New Brunswick only)

\begin{tabular}{|c|c|c|c|c|c|c|}
\hline AGES & \multicolumn{2}{|c|}{ Quebec } & \multicolumn{2}{|c|}{$\begin{array}{c}\text { New } \\
\text { Brunswick }\end{array}$} & \multicolumn{2}{|c|}{$\begin{array}{c}\text { Total } \\
\text { Male Female }\end{array}$} \\
\hline $\begin{array}{c}<1 \text { year } \\
1-9 \\
10-19\end{array}$ & $\begin{array}{r}21 \\
29 \\
9\end{array}$ & $\begin{array}{r}12 \\
26 \\
8\end{array}$ & $\begin{array}{l}4 \\
5 \\
4\end{array}$ & $\begin{array}{r}3 \\
4 \\
10\end{array}$ & $\begin{array}{l}25 \\
34 \\
12\end{array}$ & $\begin{array}{l}15 \\
30 \\
18\end{array}$ \\
\hline TOTALCHILDREN & 58 & 46 & 13 & 17 & 71 & 63 \\
\hline $\begin{aligned} & 20-29 \\
& 30-59 \\
> & 60\end{aligned}$ & $\begin{array}{r}10 \\
8 \\
4\end{array}$ & $\begin{array}{r}4 \\
11 \\
3\end{array}$ & $\begin{array}{l}4 \\
0 \\
5\end{array}$ & $\begin{array}{l}0 \\
4 \\
1\end{array}$ & $\begin{array}{r}14 \\
8 \\
9\end{array}$ & $\begin{array}{r}4 \\
15 \\
4\end{array}$ \\
\hline TOTAL ADULTS & 22 & 18 & 9 & 5 & $\overline{31}$ & 23 \\
\hline TOTAL PATIENTS & 80 & 64 & 22 & 22 & 104 & 86 \\
\hline TOTAL & & 44 & & 44 & & 90 \\
\hline
\end{tabular}

The different provinces of Canada keep records of shunting procedures through differing health schemes, and not all provinces designate the type of shunt inserted. However, of the 1,973 shunts which were inserted during the years 1982-1983, 1,052 were designated as to type. Of this group, 897 or $85.2 \%$ were ventriculoperitoneal Shunts, 62 or $6.1 \%$ were ventriculoatrial
Table 5: Revision Rate/Insertion Rate at Different Age Groups in Quebec and New Brunswick 1982-1983

\begin{tabular}{lccc}
\hline \hline & Revisions & Insertions & Rate \% \\
\hline$<$ 1 year & 40 & 101 & 39.6 \\
$1-9$ & 64 & 92 & 69.6 \\
$10-19$ & 30 & 54 & 55.6 \\
TOTAL CHILDREN & 134 & 247 & 54.3 \\
\hline $20-29$ & 18 & 47 & 38.3 \\
$30-59$ & 23 & 90 & 25.6 \\
$>60$ & 13 & 93 & 14.0 \\
TOTAL ADULTS & 44 & 230 & 19.1 \\
\hline TOTAL PATIENTS & 178 & 477 & 37.3 \\
\hline \hline
\end{tabular}

\section{Conclusions:}

Shunt revisions are much commoner in the childhood population and particularly in children beyond infancy.

This reflects the effect of growth on shunt function.

shunts, 6 or $0.6 \%$ were ventriculocisternostomies or Torkildsen shunts and 85 or $8.1 \%$ were lumboperitoneal shunts.

In the provinces of Quebec and New Brunswick, where accurate data are kept with regard to the age and sex of patients having shunt insertion, a total of 477 shunts were inserted during the year 1982-1983. Two hundred and sixty-four of these shunts were inserted in males and 213 in females. Two hundred and forty-seven of the patients were children 19 years of age or less and 230 were adults 20 years and older.

The total cost of the 1973 insertions done in 1982-1983 would be:

$\begin{array}{lr}\text { Equipment per shunt } & \$ 500 \\ \text { Surgical fee } & 350 \\ \text { Hospital fee } & 6,000 \\ & \begin{array}{l}\$ 6,850 \times 1,973 \\ \end{array} \\ & \$ 13,515,050.00\end{array}$

The total cost of the 1,189 revisions done in 1982-1983 would be:

$\begin{array}{lr}\text { Equipment per revision } & \$ 150 \\ \text { Surgical fee } & 250 \\ \text { Hospital fee } & 6,000 \\ & \$ 6,400 \times 1,189 \\ & =\$ 7,609,600.00\end{array}$

The projected cost for the surgical management of hydrocephalus in Canada during 1982-1983 would have been $\$ 21,124,650.00$.

\section{Durability of the Device}

The original shunts were all multicomponent systems consisting of separate ventricular catheters, reservoirs, distal catheters and valves, with the components held together by firm plastic or metal connectors. The connectors can in time erode the soft silastic and so may cause the shunt to fracture. Because of this, a one-piece system was devised several years ago; it has more recently been modified to include a reservoir. ${ }^{9}$ Without such a reservoir, the shunt cannot be tested by means of percutaneous palpation nor can shunt scans be done to see if the shunt is functioning. 
The silastic itself can become encrusted with calcium, which can cause the silastic tubing to weaken and break. Originally, the shunt tubes were very thin-walled and kinking of the tube was a common phenomenon. In order to prevent kinking, wire reinforced tubes were introduced. Unfortunately, the wire would cut through the silastic and lead to shunt breakage. Being firm, they tended also to perforate abdominal visci. ${ }^{9}$ In recent years, kink resistant tubing has been created by making the silastic tubing thick-walled.

\section{Factors Influencing the Mode of Operation of Shunting Devices}

All the current shunts are manufactured to open at a specific preset pressure at which CSF is allowed to enter into the chamber into which the shunt flows. No commercial shunt at the present time regulates CSF flow. They are all pressure dependent. Thus the flow through a shunt can be very rapid if the pressure in the CSF chamber is above the opening pressure of the shunt. In addition to the opening pressure of the shunt valve, the flow through the shunt depends on the pressure in the viscus into which the shunt drains as well as the siphoning effect produced by hydrostatic forces.

In the upright individual, this hydrostatic force can be far higher than the opening pressure of the shunt plus the pressure within the system into which the shunt drains, and can consequently lead to a markedly negative intracranial pressure. ${ }^{9}$ This state of affairs is actually beneficial to the young infant who has open widely split sutures and large ventricles. One needs a negative pressure in these infants in order to encourage the brain parenchyma to thicken, the ventricles to come down in size and the sutures to come together. However, in the older child or adult with a closed box-like skull, this negative pressure produces slit-like ventricles which are much smaller than those of normal individuals. The ventricular ependyma can then block the openings into the ventricular catheter and lead to shunt obstruction. Numerous techniques have been used to deal with this. The Garner balloon catheter* was made with an inflatable balloon at the end of the ventricular catheter to keep the walls of the ventricle away from the tip of the shunt. This particular device was not ideal; if the balloon failed to empty, it could lead to an inflated balloon being pulled through the brain at the time of revision of a blocked shunt. Flanged ventricular catheters were introduced to cover the holes in the catheter during introduction of the shunt. However, the flanges tend to attract debris and choroid plexus often making the removal of a flanged catheter difficult.

Antisiphon devices were introduced to shut off the flow once a negative pressure occurred. ${ }^{10}$ These devices do in fact do this, but they cannot be inserted in young infants in whom negative pressure is necessary. In the older child and adult, they are a very useful adjunct to prevent the slit ventricle. What is needed however, is a variable pressure valve so that the opening pressure can be changed as the child grows in height and the demands on the shunting system are changed.

Many of the original multicomponent systems included a reservoir which fits into the burr hole. Consequently, the connector which connected the reservoir onto the ventricular catheter was about $1 \mathrm{~cm}$ from the burr hole. The problem with

*Manufactured by American Heyer-Schulte Corp. . 600 Pine Avenue, Goleta, CA, U.S.A. 93017 connections at brain surface was that in revising the shunt (when and if it blocked) there was always the risk of losing the ventricular catheter. In more recent years, all of the companies have come out with either right-angled catheters or external right-angle stints which will bend a straight catheter into a right angle so that connections can be made at skull level outside the burr hole to a flat reservoir situated on the skull. With such systems, loss of ventricular catheters during shunt revision can be avoided.

A major problem with shunts is infection. It is estimated that there is about an $8 \%$ risk of shunt infection. Infection is usually by a skin organism, Staphylococcus epidermidis. Once the shunt is infected, the usual treatment is removal of the entire device, frequently with an interposed period of external ventricular drainage. Prevention of shunt infection remains the goal of all neurosurgeons. To this end, the use of prophylactic antibiotics has been advocated, as has that of local antibiotics to soak the shunt tubing; proper cleansing of the skin and draping of the skin with antiseptic treated adherent plastic drapes have also been advocated. There is no clear answer as to whether any of these techniques truly reduce shunt infection. However, centres which have promoted the use prophylactic antibiotics report shunt infection rates below $2 \%{ }^{~ " ~}$

Current shunts are all made of silastic. This material functions well when implanted. However, after 5-10 years of implantation, the silastic frequently gathers calcific concretions, loses tensile strength and may fracture.

Since CSF production is rarely if ever more than $20 \mathrm{ml} / \mathrm{hr}$, it is evident that CSF shunts should not readily allow flow rates greater than 20 to $30 \mathrm{ml} / \mathrm{hr}$.

The current shunt systems show little variation in pressure with increasing flow rates (Table 6). However, one company is ready to release a shunt whose pressure characteristics rise steeply with flow rates above 20 to $30 \mathrm{ml} / \mathrm{hr}$.

In the child with huge ventricles in whom a shunt is inserted, one may obviously want to reduce ventricular size quite rapidly and have an initial flow rate significantly greater than that of CSF production. When the ventricles come down to a more normal size, the flow rate should be no higher than the production rate; this would maintain ventricular volume at a normal set size.

With ultrasound and CT scanning one can accurately monitor ventricular size. With a percutaneously adjustable flow rate one should be able to maintain ventricular size at a predetermined level and thus avoid the problems that we currently see with slit ventricles and subsequent shunt obstruction.

\section{Characteristics of Current Commercial Shunts}

All shunt companies produce shunts in 3 pressure ranges: low, medium and high. The pressure flow characteristics of these shunts vary according to the manufacturer (Table 6).

The low pressure shunts vary from pressures of $20 \mathrm{~mm}$ of water to $100 \mathrm{~mm}$ of water, at flow rates of $5 \mathrm{ml} / \mathrm{hr}$ to pressures of $30 \mathrm{~mm}$ of water to $190 \mathrm{~mm}$ of water, at flow rates of $50 \mathrm{ml} / \mathrm{hr}$.

The medium pressure shunts show similar differences with pressure varying between $30 \mathrm{~mm}$ of water to $160 \mathrm{~mm}$ of water, at flow rates of $5 \mathrm{ml} / \mathrm{hr}$ to pressures of $60 \mathrm{~mm}$ of water to $260 \mathrm{~mm}$ of water, at flow rates of $50 \mathrm{ml} / \mathrm{hr}$.

The high pressure shunts again vary from $50 \mathrm{~mm}$ of water to $260 \mathrm{~mm}$ of water at flow rates of $5 \mathrm{ml} / \mathrm{hr}$ to pressure of $95 \mathrm{~mm}$ of water to $425 \mathrm{~mm}$ of water, at flow rates of $50 \mathrm{ml} / \mathrm{hr}$. 
Table 6

\begin{tabular}{|c|c|c|c|c|c|}
\hline \multirow{2}{*}{$\frac{\text { Shunt }}{\text { Holter }}$} & \multirow{2}{*}{$\begin{array}{l}\text { Pressure } \\
\text { Labelled }\end{array}$} & \multicolumn{4}{|c|}{$\begin{array}{l}\text { Pressure Reached } \\
\text { Im } \mathrm{H}_{2} \mathrm{O} \text { ) at Flow Rates } 0 \text { ) } \\
\mathrm{r} 20 \mathrm{ml} / \mathrm{hr} 35 \mathrm{ml} / \mathrm{hr} 50 \mathrm{ml} / \mathrm{hr}\end{array}$} \\
\hline & & $\begin{array}{l}100 \\
160 \\
260\end{array}$ & $\begin{array}{l}160 \\
205 \\
330\end{array}$ & $\begin{array}{l}185 \\
250 \\
390\end{array}$ & $\begin{array}{l}190 \\
260 \\
425\end{array}$ \\
\hline Holter-Hausner & $\begin{array}{l}\text { Low } \\
\text { Medium } \\
\text { High }\end{array}$ & $\begin{array}{r}80 \\
100 \\
90\end{array}$ & $\begin{array}{r}90 \\
120 \\
170\end{array}$ & $\begin{array}{l}110 \\
170 \\
200\end{array}$ & $\begin{array}{l}120 \\
180 \\
200\end{array}$ \\
\hline Cordis-Hakim & $\begin{array}{l}\text { Low } \\
\text { Medium } \\
\text { High }\end{array}$ & $\begin{array}{r}80 \\
100 \\
120\end{array}$ & $\begin{array}{r}80 \\
100 \\
130\end{array}$ & $\begin{array}{r}90 \\
100 \\
130\end{array}$ & $\begin{array}{r}90 \\
100 \\
150\end{array}$ \\
\hline Denver & $\begin{array}{l}\text { Low } \\
\text { Medium } \\
\text { High }\end{array}$ & $\begin{array}{l}60 \\
70 \\
90\end{array}$ & $\begin{array}{r}90 \\
95 \\
110\end{array}$ & $\begin{array}{l}100 \\
110 \\
170\end{array}$ & $\begin{array}{l}110 \\
120 \\
190\end{array}$ \\
\hline $\begin{array}{l}\text { Heyer-Schulte } \\
\text { (Mischler) }\end{array}$ & $\begin{array}{l}\text { Low } \\
\text { Medium } \\
\text { High }\end{array}$ & $\begin{array}{l}75 \\
70 \\
90\end{array}$ & $\begin{array}{l}110 \\
100 \\
130\end{array}$ & $\begin{array}{l}150 \\
110 \\
175\end{array}$ & $\begin{array}{l}150 \\
110 \\
200\end{array}$ \\
\hline Pudenz-Schulte & $\begin{array}{l}\text { Low } \\
\text { Medium } \\
\text { High }\end{array}$ & $\begin{array}{r}80 \\
140 \\
205\end{array}$ & $\begin{array}{r}95 \\
150 \\
210\end{array}$ & $\begin{array}{r}95 \\
150 \\
210\end{array}$ & $\begin{array}{r}95 \\
150 \\
210\end{array}$ \\
\hline Codman Unishunt & $\begin{array}{l}\text { Low } \\
\text { Medium } \\
\text { High }\end{array}$ & $\begin{array}{l}20 \\
30 \\
50\end{array}$ & $\begin{array}{l}25 \\
50 \\
80\end{array}$ & $\begin{array}{l}30 \\
60 \\
90\end{array}$ & $\begin{array}{l}30 \\
60 \\
95\end{array}$ \\
\hline $\begin{array}{c}\text { Dow Corning } \\
\text { Ames }\end{array}$ & & 120 & 175 & 195 & 195 \\
\hline
\end{tabular}

(after Watts \& Keith ${ }^{15}$ )

Although CSF is characteristically water-like in consistency, it may on occasion contain large amounts of protein, cellular debris and particulate matter. These can clog the shunt, particularly at the narrow lumen segments, namely the connectors. One-piece systems avoid connectors and may be less prone to clogging.

Most of the closed end distal tubes have a segment of tubing distal to the slit valve in which debris can collect and eventually block the slits of the slit valve: In order to deal with this problem, one company has a distal closed end catheter with a series of slits proximal to the end of the catheter; another company has slits which come down to the end of the catheter and several companies provide open-ended distal catheters which rely on proximal-valve control.

\section{Shunt Failure Leading to Operative Revision is due to Multiple Factors}

(a) Shunts are typically made of separate components which can come apart or fracture, thus obstructing the shunt. In recent years, the development of one-piece systems has done a great deal to do away with this cause of shunt malfunction.

(b) Technical problems with shunt placement are common. The ventricular catheter functions best when it is in the frontal horn of the ventricle, remote from choroid plexus. Improper techniques can lead to placement of the ventricular catheter in other sites within the ventricular system or even in brain substance. The use of intraoperative ultrasound should lead to proper placement of ventricular catheters. The distal catheter must be placed in the appropriate cavity. In the case of the peritoneal cavity, many people have advocated placement by trocar which can lead the catheter into a bowel, bladder and vessel lumen rather than free peritoneal cavity. Open operation with proper exposure of peritoneal cavity should avoid such problems. In the case of an atrial catheter, the catheter must be left within the right atrium and not put through the tricuspid valve into the right ventricle or even into the pulmonary artery. The use of ECG control during placement of the atrial catheter should prevent such problems.

(c) Valve components must be properly chosen (12). For instance, insertion of a medium pressure valve distal to an antisiphon device will lead to high pressure intracranially. Too low a pressure in the system can lead to over-drainage and collapse of ventricles. This can lead to the development of subdural hematomas or to obstruction of the ventricular catheter by ependyma.

(d) Shunt infection remains a common problem. Infection rates varying between $1 \%$ and $20 \%$ and have been reported. The average infection rate in most centres is about $8 \%$. Numerous techniques have been advocated to prevent infection. These include the use of a variety of prophylactic antibiotics, the use of antibiotics during the procedure to soak the tubing and flush the wound, "the use of antibiotics impregnated within the silastic of the tubing, and the use of the surgical isolator to prevent bacteria within the operating room air from dropping onto the shunt system. ${ }^{13}$

The commonest infecting organism is the Staphylococcus epidermidis, which comes from the patient's skin and is implanted during the course of the operation. The use of adhesive drapes, particularly those impregnated with antiseptic materials, should help to prevent skin bacteria, not adequately dealt with by surgical prepping and draping, from contaminating the shunt.

(e) Shunt breakage can occur particularly in shunts which have been implanted for several years. One-piece shunt systems tend not to break. On the other hand, once connectors (which are usually stiff) are introduced, they can with movement erode through the soft silastic and lead to shunt breakage. The use of one-piece systems should reduce breakage as a factor in shunt malfunction.

(f) Shunts can be obstructed for a wide variety of reasons. Collapse of the ventricles due to over-drainage of the shunt can lead to shunt blockage by debris from the ventricular wall. Placement of the shunt in the region of the choroid plexus will allow the choroid plexus to surround the ventricular end of the shunt and block it. Blood and protein within the spinal fluid can clog the interior of the shunt.

Shunts do not grow as the child grows and with time the distal end of the shunt will pull out of the cavity into which it drains and result in shunt obstruction.

Some of the cavities into which CSF has been drained will not adequately absorb the fluid. The pleural cavity can fail to absorb CSF and result in pleural effusions ${ }^{8}$. Occasionally, the peritoneal cavity will fail to absorb CSF, leading to ascites. If the atrial catheter pulls into the superior vena cava with growth, the superior vena cava will frequently thrombose around the tip of the shunt and prevent adequate functioning of the shunt.

\section{Shunt Revisions at the Hospital for Sick Children}

In order to assess the reasons for shunt revisions, we reviewed the causes for VP shunt revision carried out on the neurosurgical service at the Hospital for Sick Children (Toronto) during 1984.

In 1984, 198 ventriculoperitoneal shunts were revised on the neurosurgical service at the Hospital for Sick Children. One 
hundred forty-three of these revisions involved the proximal end of the shunt and 65 revisions involved the distal end. The commonest cause of shunt obstruction was debris occluding the catheter. This accounted for 84 of the 143 proximal revisions and 33 out of the 65 distal revisions.

Technical problems with shunt placement were also a common cause of shunt revision. Thirty-four of the 143 proximal revisions were due to improper placement of the ventricular catheter, and 5 of the 65 distal revisions were due to improper placement of the peritoneal catheter. Disconnection and breakage of multiple component shunts were relatively common, accounting for 11 of the 143 proximal revisions and 8 of the 65 distal revisions. Shunt migration and withdrawal were also common causes of revision, accounting for 8 of the 143 proximal revisions and 10 of the 65 distal revisions.

Two shunts were revised because of blockage due to unsuspected infection. Three revisions were due to component malfunction.

\section{Existing Test Methods to Evaluate Shunting Devices}

In anticipation of the U.S. Federal Drug Administration's passing of a law to assure the safety and efficacy of implanted surgical devices, the American Society for Testing and Materials (ASTM) prepared a document in December 1979 which recorded standards for neurosurgical shunts. ${ }^{14}$

This standard specified the type of material, mechanical properties and surface finish of the shunt, as well as the best tests available to assure biocompatability of shunt materials. The standard defined the components of the shunt system, the minimal requirements for packaging, labelling and sterility, the recommended test method for determining radio-opacity, as well as a test method for evaluating the pressure flow characteristics of valves.

The standard took approximately 5 years to write and was produced with the cooperation of neurosurgeons, shunt manufacturers, engineers and basic scientists.

The components listed in the standard were: 1 . a proximal catheter (in flow); 2 . a distal catheter (out flow); 3 . connector; 4 . valve; 5 . valve catheter; 6 . implantable accessory device. These accessory devices consisted of an antechamber, anti-siphon device, flushing device, in-line filters, on-off switch and reservoir.

Since the writing of the standard, other accessory devices have been developed including a telemetric device for measuring percutaneous pressure within the ventricle. Furthermore, a number of one-piece shunt systems without connectors, and with the proximal and distal catheter and flushing device in one system, have been developed.

\section{In Vitro Testing $14,15,16,17,18$}

The ASTM testing ${ }^{14}$ is based on the principle that the rate of flow of fluid through a shunt or shunt element is a function of the pressure which drives the fluid and the sum of the resistances of the devices, if all other factors are held constant. The test apparatus consists of a source fluid reservoir, a constant temperature water bath, a variable speed pump having flow rate in $\mathrm{ml} / \mathrm{hr}$ accurate to plus or minus $5 \%$, a water manometer or equivalent calibrated in $\mathrm{mm}$ with a $\mathrm{T}$ or $\mathrm{Y}$ connector, connecting tubing, an apparatus to maintain constant water level in the bath, the appropriate adapter for the shunt or shunt elements and the device to be tested. The $\mathrm{T}$ connector is joined to the shunt. The test fluid temperature is maintained at 37 , plus or minus 2 degrees $\mathrm{C}$; the fluid medium used for testing the shunt or shunt elements is distilled water, as is the constant temperature water bath.

All air is purged from the system. The shunt is soaked, the manometer is zeroed and the device to be tested is attached to the pump set to provide flow rates ranging between 50 and $5 \mathrm{ml} / \mathrm{hr}$.

This should lead to the production of a curve of values of the pressures produced to drive fluid through the system. For each flow rate there should be a minimum and maximum data point of pressure.

Watts and Keith ${ }^{15}$ set up a system which provided both constant and pulsed flow. They studied pressures at flow rates varying between 0.05 and $2.0 \mathrm{ml} / \mathrm{min}$. The pulse generator produced pulse frequencies of 5 to 120 cycles per minute. They concluded that since pulsed flow was the natural way of CSF circulation, that it therefore made for a better method of testing CSF shunting devices.

In vitro testing should be done with a fluid medium similar to CSF and should thus contain some protein. The tensile strength of the silastic should be tested and it should be determined if the tubing can kink, since shunt tubing should not be kinkable. Long term tests for biocompatibility and tensile strength are still necessary. Shunt tubes should be radio-opaque; this should be tested by $\mathrm{x}$-raying the tube and seeing how well it can be seen on ordinary $x$-ray. The radio opacity of the shunt components is necessary to facilitate evaluation of the integrity of the assembly and position of the individual shunt components after implantation. The ASTM and the FDA have set up criteria for establishing a radio opacity of the tube. They have suggested that a sheet of aluminum alloy \# 1100 having a thickness selected from a range of 2 to $20 \mathrm{~mm}$ and interposed between the shunt and $\mathrm{x}$-ray generator would help to determine how a shunt would look on an ordinary $x$-ray film. ${ }^{14}$

\section{In Vivo Testing}

1. Injection of radionucleide in the shunt and the use of a gamma camera to determine flow through the shunt. ${ }^{19} 2$. Cooling the fluid in the shunt and using a thermistor to see if the cool fluid is flowing along the shunt. ${ }^{20} 3$. Injection of such contrast agents as metrizamide into the shunt to see the flow down the shunt. 4. Ultrasound scanning and CT scanning to see the size of the ventricles and determine whether they have been adequately decompressed by the shunt. 5 . Ordinary $x$-ray examination to see the position of the shunt tubing as well as evidence of breakage or disconnection.

\section{Recommendations for Improving Safety}

1. All components of a shunt system should be radio-opaque so that they can be visible on ordinary $x$-rays; if pieces of tubing break or migrate, they can be detected with an ordinary $x$-ray. 2. To prevent the loss of catheters within the ventricles, no connection should be made at brain level. 3. As few connections as possible should be made in the shunt system, for silastic catheters break at sites of connection. If connections must be made, they should be made at a point where movement of shunt against body is virtually non-existent, namely at the proximal end of the shunt system. In the growing child the entire calibre of the shunt system, right up to the patient's head, should be uniform to allow the tube to slide with growth and with movement. Thus, no connections should be made below 
the level of the head, particularly in a child. 4 . The ventricular catheter should be placed in the frontal horn. Intraoperative ultrasound is ideal for ascertaining placement of the ventricular end of the shunt. 5. The use of flanged catheters should be discouraged because of the tendency of the flanges to become adherent to ependyma and choroid plexus. 6 . A reservoir should be incorporated into the shunt system to allow for percutaneous testing, aspiration of CSF and instillation of radionucleides for shunt scanning 7 . The opening pressure of the shunt should be correlated with the needs of the patient; thus, in young infants in whom a low pressure is required to encourage re-expansion of mantle, a low pressure shunt should be used; higher pressure shunts should be used in the older child or adult. Ideally, a variable pressure valve should be developed to tailor the pressure of the valve to the needs of the patient. 8 . Stringent efforts should be made to avoid shunt infection. (a) The manufacturer should provide shunts and shunt components in sterile dated packs. (b) Meticulous techniques should be used in the operating room. Soaking of shunt tubes in covered containers of antibiotic solution and the use of antisepticcoated adherent plastic draping should be encouraged. (c) Although definitive studies are not complete, there is a body of evidence which indicates that prophylactic antibiotics are of value in preventing shunt infection and there is no evidence that prophylactic antibiotics lead to shunt complications. Because of the devastating effects of shunt infection on both finances and health, we would therefore recommend the use of prophylactic antibiotics.

\section{ACKNOWLEDGEMENTS}

We would like to express our thanks to the Ministries of Health of Newfoundland, Nova Scotia, New Brunswick, Quebec, Ontario, Manitoba, Saskatchewan, Alberta, British Columbia, Yukon and Northwest Territories for providing me with information on the use of diversionary shunts in Canada as well as to Fernie Quintela for her help and patience in typing this manuscript.

\section{REFERENCES}

1. Pudenz R. The surgical treatment of hydrocephalus: A historical review. Surg Neurol 1981; 15: 15-26.

2. Torkildsen A. A new palliative operation in cases of inoperable occlusion of the Sylvian aqueduct. Acta Chir Scand 1939; 82: 117-125.
3. Matson DD. A new operation for the treatment of communicating hydrocephalus. Report of a case secondary to generalized meningitis. J Neurosurg 1949; 6: 238-247.

4. Kushner J, Alexander E, Davis CH, et al. Kyphoscoliosis following lumbar subarachnoid shunts. J Neurosurg 1971: 34: 783-791.

5. Hoffman HJ, Hendrick EB, Humphreys RP. New lumboperitoneal shunt for communicating hydrocephalus. J Neurosurg 1976; 44 : 258-261.

6. Nulsen FE, Spitz EB. Treatment of hydrocephalus by direct shunt from ventricle to jugular vein. Surg Forum 1952; 2: 399-403.

7. Ransohoff $\mathrm{J}$ : Ventriculo-pleural anastomosis in treatment of midline obstructional neoplasms. J Neurosurg 1954: 11: 295-298.

8. Hoffman HJ, Hendrick EB, Humphreys RP. Experience with ventriculo-pleural shunts. Child's Brain 1983; 10: 404-413.

9. Hoffman HJ. Technical problems in shunts. In: Shunts and Problems in Shunts. Choux M, ed, S. Karger Pub, Basel, 1982; 158-169.

10. Portnoy HD, Schulte RR, Fox JL. Croissant PD. Trip L: Antisiphon and reversible occlusion valves for shunting in hydrocephalus and preventing post-shunt subdural hematomas. J Neurosurg 1973; 38: 729-738.

11. Klein DM. Comparison of antibiotic methods in the prophylaxis of operative shunt infections. Concepts pediat Neurosurg. Karger S, Basel. 1983; 4: 131-141.

12. Watts CC. Therapeutic assist devices: Hydrocephalic shunt in Medical Devices: Measurements Quality Assurance and Standards. ASTM technical publication 800 , Caceres CA. Yalken HT, Jones RJ, Piehler HR, eds, ASTM 1983.

13. Hirsch JF, Renier D, Pierre-Kahn A. Influence of the use of a surgical isolator on the rate of infection in the treatment of hydrocephalus. Child's Brain 1978; 4: 137-150.

14. Standard practice for evaluating and specifying implantable shunt assemblies for neurosurgical application. Designation F 647-79. Prepared by ASTM committee F-4 on medical and surgical materials and devices, subcommittee, F0450 on neurosurgery, 1979.

15. Watts $C$, Keith HD. Testing the hydrocephalus shunt valve. Child's Brain 1983; 10: 217-228.

16. Watts C. Avula X, Keith HD. Pulliam M. An investigation of cerebrospinal fluid shunt valves. Final report Phase 1, 1980; USPH, FDA 223-79-5064.

17. Keith HD, Avula X, Schelich C, Watts $C$. An investigation of cerebrospinal fluid shunt valves. Final report, Phase II, 1981; USPH FDA 223-79-5065.

18. Keith HD, Lu RL, Fu CC, Shao S. Watts C. An investigation of cerebrospinal fluid shunt valves - test results for 25 valves, 1982; USPH FDA 223-79-5064.

19. Harbert J. Haddad D. McCullough D: Quantitation of cerebrospinal fluid shunt flow. Radiology 1974: 112: 379-387.

20. Stein SC, Apfel S: A noninvasive approach to quantitative measurement of flow through CSF shunts. J Neurosurg 1981:54: 556-558.

21. Walters BC, Hoffman HJ. Hendrick EB, Humphreys RP. Cerebrospinal fluid shunt infection. Influences on initial management and subsequent outcome. J Neurosurg 1984: 60: 1014-1021. 